\title{
Commentary 2 to the manifesto for the marine social sciences: applied social science
}

\author{
Marloes Kraan $^{1} \cdot$ Sebastian Linke ${ }^{2}$ \\ Published online: 3 July 2020 \\ (C) The Author(s) 2020
}

This manifesto comes at a time when the marine social sciences are increasingly recognised as a required field of knowledge for policy. Still social science is not yet fully part of mainstream fisheries science and marine science (Hind 2015; Stephenson et al. 2016; Arbo et al. 2018). Furthermore, existing sciencepolicy interfaces and advisory bodies are mainly populated by natural scientists (biologists, ecologists) and economists. Interdisciplinary research projects often entail separate work packages, with a majority focussing on natural science questions applying quantitative methods, accompanied by some stakeholder engagement work or a governance work package done by social scientists. Nevertheless, the interest in, demand for, and actual invitation to the social sciences are growing - in fisheries as elsewhere (Link et al. 2017; Shah 2020). This follows various high-level international agreements expressing holistic aspirations such as incorporating four pillars of sustainability (Stephenson et al. 2017), the ecosystem approach to fisheries (Link et al. 2017), the United Nations Sustainable Development Goals (Gupta and Vegelin 2016), or the UN Ocean Decade (Ryabinin et al. 2019). Also, the International Council for the Exploration of the Sea (ICES) aims "to develop strategies to support the integration of social and economic science into ICES work" currently realised through various working groups and a Strategic Initiative for the Human Dimension. ${ }^{1}$

The demand for social science raised by a natural science dominated domain is based on a few insights: (1) management works via people and hence understanding people's ideas and

$\overline{{ }^{1} \text { https://www.ices.dk/community/groups/Pages/SIHD.aspx }}$

Marloes Kraan

marloes.kraan@wur.nl

1 Environmental Policy Group (Wageningen University) \& Wageningen Marine Research, Hollandseweg 1, Wageningen, The Netherlands

2 Environmental Social Science, School of Global Studies, University of Gothenburg, Gothenburg, Sweden actions is a factor to take on board; (2) management itself is a human activity that requires critical reflection, (3) the way science and policy interact is important to understand for effective decision-making; (4) many societal problems are "wicked" (high uncertainty, high stakes, and limited time to act), requiring post-normal-science (Dankel et al. 2012) and new approaches to solve them (i.e. interactive governance; Kooiman et al. 2005). These considerations lead us to two key points.

First, the time for integrating social science into applied marine research is now. Increasingly, new (and some older) scholars are raised with interdisciplinary minds, integrating qualitative and quantitative methods, applying a variety of theories to field cases, and "including a human dimension" by using holistic concepts such as e.g. social-ecological systems (Arbo et al. 2018; Andrews et al. 2020). It seems that the times when social scientists complain that "they don't understand" or that "they never ask us" are over. The question for social science/scientists is thus not if but how to engage in applied contexts.

Second, the need for social science input appears primarily driven by a wish to be more effective in the uptake of science for policy- and decision-making. Many policymakers and natural scientists interested in social science methods and applications basically want to know: "how can we better influence people to do "the right thing"'? However useful, positive, and sometimes effective these aspirations might be, this approach calls for scrutiny. Critical reflection is part and parcel of the social science effort, guided by questions like: Who decides what is right and based on what? (representation); Who are winners and losers of "the right thing"? (social justice); Who has influence in this process and who doesn't? (power) and Who asks and designs the research questions? (agenda setting).

Summing up, we (marine social scientists) find that now, once we are clearly invited to join the field, we need both openness and vigilance. This means building trust for constructive ways of interacting and integrating social 
science into existing frameworks as well as changing the frameworks for including new methods and approaches, while at the same time not losing the critical strength of social science concepts and methods. This balancing act of problem-solving and critical research (Mahmoud et al. 2018) is not straightforward and requires trust, patience, and time investments, not only by social scientists but also by their various counterparts.

Although the Manifesto is primarily directed to "the epistemic community of marine social scientists" it also brings "urgent marine social science topics" to the fore for a broader audience (Bavinck and Verrips 2020). The qualification of "urgent" calls for action. For instance, the Manifesto (MMSS 1.1.3) states that "we (social scientists) must critically engage with the Blue Economy process study it and engage with protagonists in their respective forums. The rapidly changing political economy of coasts and oceans underscores the need for critical as well as constructive social-science analyses". We think that there is no better place to critically engage with this process than in the applied research arena. However, we tend to disagree with the appellation "Manifesto" as this adds a political connotation to the agenda, which may undermine the research-based value of applying social science. In addition, we feel the normative nature of some of the statements (i.e. MMSS 2.2.2 that small-scale fishers should be included in MSP and this requires supportive research; or MMSS 1.2.1, promoting diversity and sustainability of fish for food) can undermine the objective role of social science in the science-policy interface.

Open Access This article is licensed under a Creative Commons Attribution 4.0 International License, which permits use, sharing, adaptation, distribution and reproduction in any medium or format, as long as you give appropriate credit to the original author(s) and the source, provide a link to the Creative Commons licence, and indicate if changes were made. The images or other third party material in this article are included in the article's Creative Commons licence, unless indicated otherwise in a credit line to the material. If material is not included in the article's Creative Commons licence and your intended use is not permitted by statutory regulation or exceeds the permitted use, you will need to obtain permission directly from the copyright holder. To view a copy of this licence, visit http://creativecommons.org/licenses/by/4.0/.

\section{References}

Andrews, E.J., S. Harper, T. Cashion, J. Palacios-Abrantes, J. Blythe, J. Daly, S. Eger, C. Hoover, N. Talloni-Alvarez, L. Teh, N. Bennett, G. Epstein, C. Knott, S.L. Newell, and C.K. Whitney. 2020. Supporting early career researchers: insights from interdisciplinary marine scientists. ICES Journal of Marine Science. https://doi.org/ 10.1093/icesjms/fsz247.

Arbo, P., M. Knol, S. Linke, and K. St Martin. 2018. The transformation of the oceans and the future of marine social science. Maritime Studies 17: 295-304.

Dankel, D.J., R. Aps, G. Padda, C. Röckmann, J.P. van der Sluijs, D.C. Wilson, and P. Degnbol. 2012. Advice under uncertainty in the marine system. ICES Journal of Marine Science 69: 3-7.

Gupta, J., and C. Vegelin. 2016. Sustainable development goals and inclusive development. International Environmental Agreements 16: 433-448.

Hind, E.J. 2015. A review of the past, the present, and the future of fishers' knowledge research: a challenge to established fisheries science. ICES Journal of Marine Science 72: 341-358.

Kooiman, J., M. Bavinck, S. Jentoft, and R. Pullin, eds. 2005. Fish for Life: Interactive Governance for Fisheries. Amsterdam: Amsterdam University Press.

Link, J.S., O. Thèbaud, D.C. Smith, A.D.M. Smith, J. Schmidt, J. Rice, J.J. Poos, C. Pita, D. Lipton, M. Kraan, S. Frusher, L. Doyen, A. Cudennec, K. Criddle, and D. Bailly. 2017. Keeping Humans in the Ecosystem. ICES Journal of Marine Science 74: 1947-1956.

Mahmoud, Y., A. Jerneck, A. Kronsell, and K. Stehen. 2018. At the nexus of problem-solving and critical research. Ecology and Society 23 (4): 40. https://doi.org/10.5751/ES-10458-230440.

Ryabinin, V., J. Barbière, P. Haugan, G. Kullenberg, N. Smith, C. McLean, A. Troisi, A. Fischer, S. Aricò, T. Aarup, P. Pissierssens, M. Visbeck, H.O. Enevoldsen, and J. Rigaud. 2019. The UN Decade of Ocean Science for Sustainable Development. Frontiers in Marine Science 6. https://doi.org/10.3389/fmars.2019.00470.

Shah, H. 2020. World View. Global problems need social science. A personal take on science and society. Nature 577: 295. https://doi. org/10.1038/d41586-020-00064-x.

Stephenson, R.L., S. Paul, M.A. Pastoors, M. Kraan, P. Holm, M. Wiber, S. Mackinson, D.J. Dankel, K. Brooks, and A. Benson. 2016. Integrating fishers' knowledge research in science and management. ICES Journal of Marine Science 73 (1): 459-1465.

Stephenson, R.L., A.J. Benson, K. Brooks, A. Charles, P. Degnbol, C.M. Dichmont, M. Kraan, S. Pascoe, S.D. Paul, A. Rindorf, and M. Wiber. 2017. Practical steps toward integrating economic, social and institutional elements in fisheries policy and management. ICES Journal of Marine Science 74: 1981-1989. https://doi.org/ 10.1093/icesjms/fsx057.

Publisher's note Springer Nature remains neutral with regard to jurisdictional claims in published maps and institutional affiliations. 